\title{
BUSINESS COMMUNICATION EDUCATION IN THE UNITED STATES
}

\author{
Herbert W. Hildebrandt et al. \\ University of Michigan
}

\begin{abstract}
A statement prepared by the Graduate Studies Committee of the American Business Communication Association. Kenneth C. Rison, William G. Savage, Frances L. Uskup, Michael C. White, Mary Vielhaber, Co-Chairperson, and Herbert W. Hildebrandt, Chairperson.
\end{abstract}

The following report represents a final step in a study of graduate education in business communication by the Graduate Studies Committee of the ABCA.

In 1975 the Committee determined that at least 121 institutions offered courses in communication, housing those courses in departments of speech, literature, theatre, and others. ${ }^{1}$

The 1976 Graduate Studies Committee designed a program of study for the MBA with a concentration in business communication. That concentration demanded a minimum of 20 hours of communication work: 12 hours in courses such as communication theory and concepts, administrative communication, communication research, and organizational theory and systems. Six hours of electives were suggested in such courses as seminars in business communication; argumentation, oral and written; administrative communication in public relations; and administrative communication systems and change. ${ }^{2}$

Favorable reaction by the $\mathrm{ABCA}$ Board to the MBA proposal motivated the 1977 committee to develop a $\mathrm{Ph} . \mathrm{D}$. program in business communication. That report recommended that minimum Ph.D. communication core requirements be 18 hours in areas of advanced composition, research methodologies, information analysis, seminars in written and oral communication, and theories of persuasion and argumentation. ${ }^{3}$

The 1978 committee sought to answer this general question: which schools in the U.S. offer degrees in business communication? In other words, where could students interested in business communication go to obtain graduate or undergraduate work? We quickly add that we transgressed early in the project, including both undergraduate and graduate data in the questions and report.

\section{PROCEDURE}

The committee, after reviewing its charge, proceeded in this manner:
1. A letter was sent to the committee, discussions held on direction and methodology.

2. A brief questionnaire was constructed which sought answers from business schools to the following questions:

-May undergraduate, master or doctoral students receive a degree with a concentration in business communication?

-What are the requirements for that concentration?

- May students minor in courses relating to business communication?

-Are any courses in business communication offered?

3. The questionnarie was sent to the 537 Deans of Business schools who were members of The American Association of Collegiate Schools of Business (AACSB).

4. Committee members were assigned geographic regions of the country and contacted those business schools within their area which were not members of the AACSB.

5. All questionnaires, course outlines, requirements were returned to the chairperson or vicechairperson for collation.

6. Statements involving specific schools were checked with respondees from those schools.

7. A draft statement was given members of the committee for their reaction.

\section{RESULTS}

The Ph.D.

We must again state $^{4}$ that no Ph.D. program solely entitled business communication exists. Research into degree titles of the AACSB further supports that presumption. ${ }^{5}$ Indeed, a statement made by the 1977 graduate committee is still the majority position: "There are students who concentrate in communication, often in speech departments, meet course and hour requirements for that area, but complete a dissertation which falls into the 
category of business communication. The dissertation is business communication; the academic training is departmental and interdepartmental." 6

However, the University of Texas at Austin, Department of General Business, offers a Ph.D. major in business and organizational communication. At the core of the program is a course ( $\mathrm{BC} 380$ ) for the Ph.D. candidate and includes topics such as Research Methodology in Business Communication, Administrative Communication, Behavior Modification in the Organization, Nonverbal Communication, and others. Two minors are also required for the degree, one of them preferably outside the College of Business.

The University of Georgia College of Business Administration, Department of Management, permits a special emphasis in organizational communication while doing graduate work in management. Thus one may obtain a Ph.D. majoring in Organizational Behavior in a program that consists of 35 hours. Of these, 20 hours are in the area of Communication and 15 are in the area of Organizational Behavior. In addition, the student has a related field of 20 hours and a research methodology requirement. A department statement suggests that: "The content of these communication courses is drawn from a wide variety of disciplines and is primarily behavioral in nature."

The usual approach is to pursue a $\mathrm{Ph} . \mathrm{D}$. degree in a nonbusiness discipline, as for example the School of Interpersonal Communication, at Ohio University in Athens, and then take business courses to complete the doctoral program.

It is our assumption that courses in business communication or other communication classes may be elective adjuncts to the Ph.D. in business.

\section{The MBA}

One school, as determined by our survey, offers a masters degree in business communication: The Master of Science degree in Technical Communication in the Department of Language, Literature, and Communication at Rensselaer Polytechnic Institute. Their programs seek to train people as technical writers and as communication specialists. "Technical writers plan, research, write, edit, and produce technical materials for professional audiences. They prepare reports, instruction books, proposals, promotional brochures, displays, exhibits, articles, speeches, TV and film scripts, and audiovisual aids in government, industry, and the academic community...." 8
Communication specialists are trained to "... theoretically analyze and perform empirical research on communication processes in specific situations to provide methods that will improve the efficiency of information exchange. . .."9

Core courses at Rensselaer include communication theory, writing, and editing; other choices include modern writing for publication, graphics, and computer applications in communication; theories of rhetoric; language and its uses; or visual communication. Students are also urged to take communication courses in other departments of Rensselaer.

Other schools offer the traditional MBA core courses with students permitted to concentrate in communication. The University of Texas at Austin includes core business courses, but also such optional communication courses as the job getting process, business report writing, behavioral communication, and communication research for organizations.

The above patterns are typical: MBA students meet core requirements in accounting, marketing, statistics, operations research, finance, and others, but may elect business communication courses as electives, either within the business school if such courses are offered, or another school of the university. Such latitude was evident at both the graduate and undergraduate level of the following schools.

-Eastern Kentucky University, College of Business

-The University of Iowa, College of Business Administration, Department of Business Education

-Eastern Michigan University, College of Business

-The University of Michigan, Graduate School of Business Administration

-Southern Illinois University at Carbondale, Department of Administrative Sciences

-Oklahoma State University, College of Business Administration

-University of Illinois at Urbana-Champaign, College of Commerce and Business Administration

-Eastern New Mexico University, College of Business

-University of Miami, School of Business Administration

-Western Kentucky University, Department of Business Education and Office Administration

Undoubtedly there are other business schools which allow business communication electives. Based on our response the above schools made specific mention of that choice. 
Three schools responding to the survey offered masters degrees which some would position in the orbit of business communication; others would not. We include a brief description of each.

A master of science degree in marketing communication at Roosevelt University includes business communication, but also more. The degree requires a minimum of $\mathbf{3 0}$ graduate credit hours in courses as contemporary problems in marketing communication, communication and consumer behavior, research in marketing communication, message strategy for marketing communication, visual communication and graphics, language and culture, or electronic communication. The goal of the degree is to prepare persons for various communication careers in public relations, publicity, copywriting, graphic work, catalogue writing, direct mail, and ad agencies.

Another variation is the Master of Arts degree in communication offered by Fairfield University, Graduate School of Corporate and Political Communication, Fairfield, Connecticut. Thirty-three credits of course work are required in areas entitled concepts and theories; research courses; media and methods; and contexts. Under those rubrics are courses such as human communication; communication systems and theories; persuasion and systematic communication; attitude and public opinion laboratory; sign, symbol, image; writers' workshop; international communication; and about 40 others.

A Graduate Certificate may be added to the Master of Arts Degree by adding 12 credits in professional writing and 6 credits in other media of human expression. Also available is a Graduate Certificate in video planning, expression, writing production (M.A. plus 12 credits).

The American University in Washington offers a Master of Science degree in public relations. One course description will suffice as a sample of the work required.

Propaganda and Persuasion (3) Attitudes and public opinion; how they have been influenced in past and present through propaganda techniques. Specific topics include formation of attitudes, attitude change, nature of public opinion, public opinion measurement, how PR practitioners attempt to persuade, historical uses of propaganda, and propaganda-good, bad, or neither. ${ }^{10}$

As a final comment, member schools of the AACSB offer 274 different degree titles. One hundred ten, or 40 percent, were for the master level degree. None included the phrase business communication in their title. ${ }^{11}$

\section{Undergraduate}

A complete picture of business communication courses and degrees in the U.S. demanded a question relating to undergraduate business communication work.

At Baylor University's Hankamer School of Business, Department of Business Communications and Business Education, students may receive a BBA degree in business communications. That major is narrowly defined and directed at persons who are preparing to be executive and administrative secretaries. Central to the degree are two core courses: integrated business writing and speech for professional people. Other required courses are typewriting; shorthand, dictation and transcription; and advanced office procedures. Thus the degree is for persons planning a career in the secretarial field.

A more traditional BBA degree, with a major in business communication is offered at Western Michigan University, College of Business, Department of Business Education and Administrative Services. There the BBA in business requires 24 hours for a major and 18 hours for a minor. Their program looks like this:

-Information Writing

- Business Communication

- Organizational Communication

- Teaching Internship

-Intemship (individual, nonteaching)

-Advanced Business Writing

-Report Writing

- Topics in Business Communication (may be repeated for credit as long as topic is different), communication systems, persuasive writing, organizational communication strategies, communication media in business, publicity and public relations

-Independent Study ${ }^{12}$

For 13 years the University of Southwestem Louisiana, College of Commerce, Business Communication has offered a B.S. degree in Business Administration with a major in business communication. The department offers four undergraduate courses: business letter writing, communication in business, business research and reporting, and independent study. Remaining requirements for the degree come from areas such as behavioral management, journalism, speech, English, and psychology. A more detailed description of the program was discussed in The ABCA Bulletin, September, $1978 .{ }^{13}$

We add that the above three schools were emphatic about offering an undergraduate degree in business communication. Others may exist and the 
committee would hope to be informed. Our data suggest that minors in business communication were also possible at the following schools:

-Baylor University, Hankamer School of Business Department of Business Communications and Business Education

-St. John Fisher College, Department of Management

-Northrop University

- Carthage College

- Texas Tech University, College of Business Administration

-Fairleigh Dickinson University, College of Business Administration

- North Dakota State University, Department of Communication

-Loyola University, College of Business Administration

- Purdue University, School of Management and Krannert Graduate School of Management

As with preceding comments, undergraduate BBA students could elect to take communication courses within their own business school or in other departments of the university. Such is the case, for example at the University of Delaware, College of Business and Economics, where one may pursue a double major: business administration within the college and communication within another college of the university.

\section{Business Communication Courses}

One conclusion is clear. There is little consistency among schools and colleges as to topic inclusions in identically titled courses in business communication. The spread of interest is wide; courses and topics range the spectrum of communication, only limited by the academic freedom and interests of the instructor and school. We will not include a list of all course titles given the committee, rather include a brief sample of both titles and descrip.tions.

-Business communication

-Communication for management

-Report writing

-Theory, information retrival and dissemination

-Communication in business

-Communication skills for executives

-Seminar in administrative communication

- Managerial communication

-Business correspondence

-Written and oral communication
-Sales communication

- Organizational communication

- Communication and change

-Interpersonal communication in organizations

-Introduction to advertising

-Communication through group presentation

-Advertising writing

-Analysis and communication

- Management analysis and presentation

-Human public relations communications

-Administrative research writing

-Information and communications techniques

-Interpersonal dynamics

-Writing for business and industry

-Transactional analysis in business communication

-Business and professional speaking

-Business reports and communication

- Business research

-Professional communication

-Problems in business communication

While some suggested course descriptions were included in the 1976 committee report, the following examples are taken directly from school descriptions, simply to suggest the range of interests and scope of what is considered business communication.

GENAD 3223, Organizational Communication

Communication theory and process; common and special problems associated with interpersonal and organizational communications affecting business decisions and operation ... (Oklahoma State University)

\section{Written Communication}

This course recognizes past instruction in language arts and emphasizes improvement in the use of language skills in oral as well as written expressions. (Southern Ohio College, Hamilton Campus)

\section{Analysis of Communication for Business}

Analysis of the methods of investigation, organization, and presentation of business data. Consideration of the factors underlying the composition of written business communication . . . (California State University, Northridge)

\section{Interpersonal Dynamics}

A group centered experience and participation in the dynamic development of the small group. Major 
emphasis is given to the application of this experience to business management problems. (Dowling College)

\section{Business Communications}

A course designed to provide students with understanding communication theory and the behavioral approach as applied to problem-solving skills in communications. Development of the ability to communicate ideas and thoughts in oral and written expression with particular relevance to the world of business ... (Texas Tech University)

\section{Theory, Information Retrival and Dissemination}

Includes information systems, persuasive communication, business research, research reporting, and construction of short reports. (Southeastern Oklahoma State University)

\section{Administrative Research Writing}

Rationale, organization, and preparation of formal business research reports. Library research methods. Use of questionnaire as a research tool. Statistical applications. (The University of Oklahoma)

\section{Honors Rhetoric and Communication}

Intensive interdisciplinary study of oral and written communication in three phases: information gathering, message preparation and process, and style of delivery. Similarities and differences in the two modes of communication are made apparent and exploited to develop skill in both . . . (Rockhurst College)

\section{CONCLUSIONS}

No precise interpretation of the phrase business communication exists at either the graduate or undergraduate level. The spread of meaning allows students and schools to develop courses suited to their interests. Thus students may obtain a Ph.D. in business administration, major field in management with an emphasis in interpersonal and organizational communication at The University of Georgia College of Business Administration; a major in business and organizational communication at the University of Texas at Austin; or students may concentrate their Ph.D. work in other schools or departments but take courses in schools of business.

At the masters level, options and interpretations for business communication are no less. Rensselaer Polytechnic Institute trains people as writers and communication specialists, leading to a Master of Science degree in Technical Communication. More usual is the core MBA program with communication courses being elective.

Three specialist communication degrees also were discovered, but with a broader interpretation of business communication: Roosevelt University's Master of Science in Marketing Communication, Fairfield University's Master of Arts in Communication in their Graduate School of Corporate and Political Communication, and American University's Master of Science in Public Relations.

On the undergraduate level Western Michigan's BBA degree major in business communication and Southwestern Louisiana's BS degree with a major in business communication appear as the more traditional business communication concepts. Baylor's Hankamer School of Business also offers a BBA in business communication, but defines it as leading to a career in the secretarial field.

Thus the committee notes that schools offering concentrates in business communication are few. Until more schools offer a business communication emphasis, both graduate and undergraduate students are limited to few schools or creating their own degree program between another academic discipline and schools of business.

The committee is aware that some schools may offer programs in business communication not noted in this report. We encourage members of those schools to inform the chairperson of the Graduate Studies Committee.

\section{NOTES AND REFERENCES}

1. See Herbert W. Hildebrandt et al., "Proposal for a Master of Business Administration in Business Communication," The ABCA Bulletin, Vol. 40, No. 1, March, 1977, pp. 3-7.

2. Ibid., pp. 5-6.

3. See Herbert W. Hildebrandt, et al., "Proposal for a $\mathrm{Ph}$.D. Degree Program in Business Communication," The ABCA Bulletin, Vol. 41, No. 1, March 1978, pp. 1-4.
4. Ibid., p. 1 .

5. Don E. Garner, "Degree Titles of AACSB Schools," AACSB Bulletin, Winter, 1978, p. 508.

6. Hildebrandt, 1978 , p. 1.

7. Information from published pamphlet of The Department of Management, College of Business Administration, University of Georgia, n.d. 
8. Information from published pamphlet of the Department of Language, Literature, and Communication, Rensselaer Polytechnic Institute, n.d.

9. Ibid.

10. Information from published catalogue of The American University, School of Business Administration, Master of Science Program in Public Information Administration, p. 258 , n.d.
11. Garner, p. 5.

12. Information in a letter to the committee from Professor Joel P. Bowman, 12 June 1978.

13. Barron Wells, "Planning a Program for a Major in Business Communication," The ABCA Bulletin, Vol. 40, No. 3, 1978, pp. 15-20.

\title{
MAKING BUSINESS COMMUNICATION COURSES ACADEMICALLY RESPECTABLE
}

\author{
Kitty Locker \\ University of Illinois-Urbana-Champaign
}

Two years ago, Raymond Lesikar noted that one of the major challenges facing the new (and even the experienced) teacher of business communication was that of devising "a respectable course, ... one worthy of teaching at the university level-a course with sufficient rigor and academic content." This challenge raises unpleasant implications, for who would tell novice instructors in physics or philosophy or French that they must work to make their courses academically respectable?

As unpleasant as we may find the implication that business communication lacks inherent academic substance and rigor, it is nevertheless a charge which we are obligated to try to understand, assess, and answer. An honest inquiry will show us, I believe, that the charge, while exaggerated, is not groundless. There are several steps we can take as individuals and as ABCA members to increase the academic respectability of the courses we ourselves teach and of the field as a whole.

\section{THE PROBLEM}

Every ABCA member is aware that courses in business writing do not receive universal homage: each of us knows colleagues in departments of Economics or Accounting or English who respond to our statements that we teach (and even enjoy teaching) business communication with pity or barely disguised contempt. But however little respect established courses in business communication may receive, they are not likely to be challenged; scoffing colleagues in Business and English are sufficiently cautious not to attempt to abolish courses which enjoy the sanctions of time and high student enrollments. When one proposes the establishment of a program in business communication in a college or university which has never had one, however, one meets the full brunt of the skepticism and antagonism other faculty feel. Many reasons may be advanced to explain why new courses in business communication are unfeasible, unnecessary, or undesirable, but the most powerful (if sometimes unspoken) objection is that such courses do not merit inclusion in a university curriculum.

College courses may be grouped into two categories: "knowledge" courses in which the student's primary goal is to amass a body of facts or theories, and "skills" courses in which the student is taught to perform some act or process. In the academic hierarchy, "knowledge" courses rank higher than "skills" courses; in either category, the more esoteric the knowledge or more difficult the skill, the more "respectable" the course is likely to seem.

By any of the measures derived from this value system, business communication courses are likely to fare poorly. Most of our courses emphasize skill rather than knowledge. Such knowledge as we do attempt to impart is easy to understand (if hard to apply) and limited in scope and extent-the hard, "academic" content of basic business communication texts seldom comprises fifty or seventy-five pages - this for a quarter or semester course! There is perhaps nothing wrong with having a limited number of basic principles - the hard sciences, after all, 